grade and residual hemicellulose content of the Australian samples are shown in the accompanying table.

It will be seen that Belgian scutching of Australian retted flax only improved the fibre by one half-grade, whereas Belgian single retting led to an improvement of four and a half grades, and there was a marked decrease in the hemicellulose content of the fibre with increasing grade. It is therefore evident that the higher quality of the Belgian-processed Australian flax is attributable to more complete retting. Why, then, did the Belgian flax yield the same grade of fibre in both countries? An explanation for this apparently anomalous result can be offered in the light of the bacteriological findings recorded above. When the Belgian flax was retted in this Laboratory (Australia), without admixture of other straw, the same retting bacteria, carried on the straw and comprising mainly $\mathrm{Cl}$. felsineum, would be active as when it was retted in Belgium, so that the same grade of fibre could be expected in both places, provided that other steps in the processing, such as scutching, were comparable. On the other hand, the small sample of Australian flax sent to Belgium was retted in the same tank with a large quantity of Belgian flax, thereby being subjected to the action of the retting bacteria of the latter material, which would pre. dominate in the tank and were presumably of a similar nature to that of the Belgian flax retted in Australia. As a result of the action of a more efficient retting flora, the full potential fibre quality of the Australian flax was realized. These results clearly support the contention that the quality of Australian flax fibre is adversely affected by the scarcity in our soils of the most efficient retting bacteria, and that at least some Australian-grown flax is potentially capable of yielding high-grade fibre.

Further confirmation of the belief that Australian flax would benefit by retting with $C l$. felsineum has been forthcoming from a series of laboratory rets inoculated with cultures of this organism. In all cases, the inoculated rets were completed in little more than half the time required by the uninoculated, and the fibre from the former was noticeably superior to that from the latter in fineness, cleanness and lustre, with improvements ranging from one half to three grades. The degree of improvement resulting from inoculation of the rets was governed by the inherent fibre-strength of the flax samples. Some were weakened too much by the more severe retting for improved grades to be obtained, but the stronger types suffered no appreciable weakening and benefited greatly by the more complete removal of encrusting hemicellulosic material.

This work is being extended with the object of finding an economical method of introducing the more efficient retting bacteria, such as $\mathrm{Cl}$. felsineum, into commercial retting in Australia. Should this be possible, a considerable improvement in the quality of much Australian-grown flax may be anticipated.

The work described is a part of the investigations being carried out by the Flax Research Laboratory of the Commonwealth Scientific and Industrial Research Organisation.

'Carbone, D., and Tombolato, A., Le Staz. Sper. Agrar. Ital., 60, 563 (1917).

Orla-Jensen, A., and Kluyver, A., Z. Bakt. Parasitenk., Abt. II, 101, Tarkova, Z. S

'Ruschmann, G., and Bartram, H., Z. Bakt. Parasitenk., Abt. II, 105,326 and 433 (1943).

- Enebo, L., Acta Agric. Suecana, 2, 319 (1947).

- Allen, L. A., J. Soc. Chem. Indust., 65, 365 (1946).

\section{THE WORLD'S FOOD AND BRITAIN'S NEEDS}

$\mathrm{T}$

HE Association of Scientific Workers held a conference in London during March 4-5, on "The World's Food and Britain's Needs". While some speakers provided the technical background of food supply from the land and sea and described the possibilities of pest control and new food preservation, Lord Boyd-Orr, Dr. Julian Huxley and Mr. F. Le Gros Clark gave overall surveys of the problem of supplying food to an ever-increasing world population desiring a rising standard of living. In all cases it was the supply of food which wes discussed, not nutritional requirements, which were adequately dealt with in the British Medical Association's report published the day before.

Dr. Huxley started by giving a grim picture of the acceleration in world population, and pointed out that even if the rate of increases were declining (and it is not) there would still be net increases for some time to come. The decreasing population in Great Britain and some other Western European countries which alarmed us before the Second World War was a local phenomenon - and even in this area the tendency has since been reversed. We all know of the enormous population increases in the Far East (Formosa has doubled its population in less than thirty years; in 1872 Japan had 32 millions, now there are more than 80 millions), but fow of us realize that Egypt has doubled its population during this century, and there are other equally startling figures.

Of the present world population of approximately 2,200 million (contrast 920 million for the year 1800 and only about 545 million for 1650), a half or twothirds suffer from malnutrition. This means that, even without allowances for further population increases, a big increase in food production is needed. Why has food production not kept up with increases in population? Apart from the ravages of war, Dr. Huxley enumerated several cases of bad husbandry on a national level, such as the excessive tree felling in the Lebanon, Yugoslavia and Greece, the cultivation of steep slopes without suitable contouring, and allowing previously irrigated land to go back to arid desert. He said that the soil erosion on Haiti, with its $3 \frac{1}{2}$ million inhabitants on 10,000 square miles, must be seen to be believed.

Mr. Le Gros Clark hit hard at those who ask what is the use of saving thousands from malaria and other diseases in order that they may die of hunger. $\mathrm{He}$ insisted that nothing could hold back medical science, which is the pacemaker for agricultural science. Agriculture has the problem of increasing output fifty to a hundred times in the next fifty years, and, while medicine could save thousands of lives by sending a small band of trained men to clear an area of, say, malaria, despite the ignorance of the inhabitants themselves, on the other hand agriculture cannot be improved without the active co-operation of millions of backward peasants, "oppressed by all the evils which can oppress them". "These evils must be swept away before we get the model producer we want. What is needed is an Agricultural Revolution changing farming methods and social relationships as profoundly as the Industrial Revolution changed our lives a hundred and fifty years ago.

In the opinion of Dr. Bunting, chief scientific officer of the Overseas Food Corporation, what is perfectly possible technically is impossible socially, 
but Lord Boyd-Orr (whose address was read in his absence through illness) stressed that "there can be no social contentment or peace in the world so long as the majority of the people lack food and believe that under a new order they can get it".

Not only must the backward peasant be educated, but also the industrial worker must learn to play his part more fully. In his summing up on the second day of the conference, Mr. Le Gros Clark suggested to the delegate from the United Nations Educational, Scientific and Cultural Organisation (Mr. M. Goldsmith) that what is needed is not so much information about agricultural methods in different countries as stimulation of the industrial workers (90 per cent of the population of Great Britain) to consider better their possible contributions towards the improvement of methods and machinery of agriculture. This would not only be in the interests of agricultural communities, but also in our own. Despite the record of famines in India over the centuries, if India and Great Britain were both forced to stop importing food, the Indians would survive longer than we should.

Sunday morning was devoted to the specific problems of improving food production in Britain and of preventing loss of food through pest infestation.

Sir George Stapledon said it is foolish for us to let our wheat acreage fall below the three million mark and asserted that the East Anglian counties did not produce the wheat they should, even at the height of war-time effort. However, he warned, farming to the hilt depends on our obtaining sufficient phosphates and potash.

Dr. G. A. Reay, in talking on fish utilization (he was concerned only with marine fish and made no reference to freshwater fish), pointed out that freezing white fish at sea would mean a considerable saving of steaming time for boats, which often have to return half-empty in order that the fish already caught should not lose its freshness before consumption. Development of freezing plant would also help the eanning of fish, as it would enable a constant supply of fish to be available, for no canning factory can work profitably if it only receives seasonal supplies.

Mr. S. A. Barnett, who is head cf a research unit on mammalian pests in the Ministry of Agriculture and Fisheries, emphasized that for efficient pest control not only must the scientific worker study the natural history, that is, the life-cycle, habits, etc. of the pest, but also there must be an informed public. It is no use setting traps for rats in India while the Indians go round the traps releasing the caught rats. Not only co-operation between the scientific worker and the public is necessary, but also for many pests international control is essential. International study and control have already proved effective in combating the African red locust and the Colorado beetle, and are under way for the periodic plagues of field mice which occur in Europe and the Soviet Union.

The discussion after the main speeches was more concerned with the politico-ethical/social aspects than with purely technical problems. But the main speakers asked that various lines of research should be undertaken. Sir George Stapledon wanted research on the differential extraction power of different plants on different soils, regarding essential chemicals ; Dr. Reay wanted engineers to tackle the problems connected with freezing fish at sea, and, finally, Mr. Le Gros Clark asked for a real study of the 'natural history' of famines. There are too many people willing to sacrifice themselves and their money on relieving famines which have already got out of hand, and there is not enough research into what leads up to a famine situation.

Lord Boyd-Orr appeared in Paul Rotha's film, "The World is Rich", which was shown at the opening of the proceedings, and Dr. D. McClean, of the Lister Institute, read the address he had prepared. He described how food shortages in the past have been responsible for revolutions and described how, in our day, the revolt against hunger and poverty in Asia has produced the most pressing political problem ; but, "in a sane world", the enormous surpluses accumulat. ing in one part of the world and the scarcity of food encouraging revolt in other parts should cancel out. Can we ensure that this world of ours is sane? The world food plan of the Food and Agriculture Organisation to double world food production in twenty-five years was put forward in 1946, but the world has not taken sufficient heed of it yet, and the end of BoydOrr's speech is worth quoting in full :

"The doubling of world food production would call for an enormous volume of industrial products, many schemes like the T.V.A., plans to stop soil erosion and recondition wastage soils, tractors and farm implements and vast quantities of consumer goods for the agricultural population. These constitute 65 per cent of the gainfully employed people of the world. With an assured market at a price at or near parity with industrial products, the purchasing power of food producers would be more than doubled. To carry out such a plan would require credits to countries to enable them to purchase the industrial equipment and to provide a world fund to ensure that everything produced could be sold. The World Bank was set up for that very purpose. If all nations were willing to co-operate in a great scheme of this kind of development of the potential resources of the earth and contribute to an international fund in proportion to their wealth, those having no money putting in an I.O.U. which would be honoured when their natural resources were developed, the world would be well on the way to the abolition of hunger, poverty and preventable diseases and to agricultural and economic prosperity with a doubling and redoubling of world trade. And most important of all, if the nations co-operated on definite concrete plans of benefit to all, the idealogical differences which separate nations would in time lose their significance."

A. M. Bassadone

\section{UNIVERSITY OF BIRMINGHAM VICE-CHANCELLOR'S REPORT}

$T$

$\mathrm{HE}$ vice-chancellor of the University of Birmingham, Sir Raymond Priestley, recently made his annual report to the Court of Governors, and among other matters of interest, he dealt with the relation between universities and technology. The Second World War revealed the comparative scarcity of highly trained technologists in Great Britain as compared with the United States and Germany. Since the War a deliberate assessment of Britain's needs in this respect has been or is being made. The earliest pronouncement was the Barlow Report, which broadly stated that the output of scientific workers from the universities should be doubled; last December the Ministry of Labour and National Service issued five pamphlets which dealt with the national need for physicists, chemists, geologists, 